\title{
Exploring Grade 6 mathematics teachers' use of the language of learning and teaching in assessment for learning
}

\section{Sizwe B Mahlambi}

Curriculum and Instructional Studies, College of Education, University of South Africa, Pretoria, South Africa emahlasb@unisa.ac.za

https://orcid.org/0000-0001-5691-8214

\section{Ailwei S Mawela}

Curriculum and Instructional Studies, College of Education, University of South Africa, Pretoria, South Africa mawelas@unisa.ac.za

https://orcid.org/0000-0002-7043-8716

(Received: 8 September 2020; accepted: 2 February 2021)

\section{Abstract}

In this study, we aimed to explore Grade 6 mathematics teachers' use of English, the language of learning and teaching in assessment for learning in selected primary schools in Alexandra Township, South Africa. From Grade 4, English is the language of teaching and learning for most learners, despite English being the home language of a minority of learners. Results of studies have shown that in South Africa, in Grades 1 to 3, in which learners are taught using their home-language performance appears to be better than in Grades 4 to 6 where English as a First Additional Language (EFAL) is used for teaching and learning. Guided by qualitative case study design, we used semi-structured interviews and non-participatory observation to collect data from nine purposefully sampled Grade 6 mathematics teachers. In conjunction with the literature reviewed and the theory underpinning the study, we used themes to analyse, interpret, and discuss the data we collected. This research revealed that learners in Grade 6 struggle to understand English as the language of learning and teaching, so, to augment concept development and understanding, teachers and learners use code-switching. In the classrooms observed, this practice has become the norm to improve the performance of learners with limited language proficiency. However, because of the differences between the home language of learners and that of teachers in mathematics classrooms, code-switching is often not enough to ensure understanding.

Keywords: English as a first additional language, the language of learning and teaching, assessment for learning, mathematics, Grade 6, code-switching 


\section{Background and introduction}

Globally, there is consensus that the language that is used impacts how classrooms instruction unfolds and how learners develop academically (Boulet, 2007; Khurana \& Sharma, 2015; Naziev, 2018). Researchers agree that learners have the right to receive an education that makes sense to them in a language they understand (Riccomini et al., 2015; Trudell, 2016). The use of a language understood by learners has significant implications for providing quality education. To achieve educational objectives, learners whose home language (HL) is not English, should be taught "systematically so that they gradually transfer skills from the familiar language to the unfamiliar one" (Benson, 2004, p. 2). Many researchers have discussed the impact of language on learning and teaching (Chikiwa \& Schäfer, 2016; Naziev, 2018; Prochazkova, 2013). In this study, we extend the discussion by exploring the impact of language on Assessment for Learning (AfL) and how teachers mitigate its burden on learners whose HL is not English. Given that the South African Constitution, adopted in 1996, promotes eleven official languages, paying attention to language in education is imperative in the South African education context. HL is the language of learning and teaching (LoLT) in Grades 1 to 3 but this changes to English in Grade 4, which means that most learners are then introduced to the teaching of mathematics in English. Therefore, Grade 6 learners who are still at a developmental stage of English language proficiency learn mathematics as English second language users as Webb and Webb (2013) have reminded us.

The task of assessing mathematics in learners whose HL is not English is not simple. The Basic Interpersonal Communicative Skill (BICS) and Cognitive Academic Language Proficiency (CALP) measurements proposed by Cummins $(1979,2000)$ drew our attention to language development for second language users. BICS refers to a learner's ability to communicate, and CALP measures the learner's ability to understand and use the academic language as Khatib and Taie (2016) have noted. Cummins (1979) pointed to a direct relationship between language proficiency and the academic performance of learners. According to his theorisation of cognitive academic language proficiency (CALP), it could take five to seven years for learners to acquire the appropriate skills required for their intellectual abilities (Cummins, 2000). For learners to make sense of the content presented, they must have "command of the oral and written academic registers for their learning" (Cummins, 2000, p. 67). Therefore, the language that teachers use in mathematics assessment in Grade 6 should be appropriate to prevent learners from losing content presented to them because of the barrier inherent in the LoLT.

Mathematics is a compulsory subject from Grades 1 to 9 in South Africa. Teachers and learners use these years to build a solid foundation so that those learners who choose to do pure mathematics in Grade 10 will have acquired the necessary skills over the previous nine years. If South Africa is to meet its envisaged socioeconomic development goals, the teaching and learning of mathematics is essential (Wilson, 2015). Therefore, the content of what Grade 1 to 9 mathematics teachers teach must equip learners who go on to do mathematics in Grade 10 with the necessary skills and competencies. To evaluate where the country is in terms of skills and the effectiveness of the education system, South African 
learners compete globally in mathematics assessments such as the Trends in International Mathematics and Science Study (TIMSS) and Southern and Eastern Africa Consortium for Monitoring Educational Quality (SACMEQ). In 2015, TIMSS reported that $61 \%$ of South African Grade 5 learners cannot do the basic mathematics that covers addition and subtraction of whole numbers, that they struggle with multiplication, and cannot solve simple word problems (Mullis et al., 2016). According to SAQMEC in 2016, 34.7\% of Grade six learners are still at a basic level of mathematics (The South African Department of Basic Education (DBE), 2017).

Spaull (2013) has observed that the DBE faces poor learner performance in mathematics. The Diagnostic Report on Annual National Assessments (ANA) in 2014 revealed that around $29 \%$ of learners function at the "not achieved" and "elementary" levels in Grade six mathematics with only about $11 \%$ of learners working at "high achievement levels" (DBE, 2014, p. 76). Furthermore, learner performance continues to decline in subsequent grades with about $90 \%$ of the learners functioning at the "not achieved" level in Grade 9 mathematics and only about $1 \%$ of learners working at "high achievement" levels (DBE, 2014, p. 81).

Several factors such as anxiety could be responsible for poor performance, which is said to lower learner self-efficacy (Recber et al., 2018), and which is cited as internationally challenging (OECD, 2019). However, additional factors such as inadequately qualified teachers, ineffective teaching methods, limited instructional materials, and overcrowded classrooms as well as the poor attitude of students and the effects of their home background (DBE, 2014), as well as the problems attached to what Sepeng (2013) has called the "foreign" (p. 51), nature of LoLT, as far as the learners are concerned, could contribute to lower learner performance in mathematics.

It is assumed that by the time the learner reaches Grade 6, proficiency in the LoLT must have been achieved and, if not, this aspect could affect learner performance (Sibanda, 2017). On the one hand, Henderson and Wellington (1998) pointed out the link between the language used in the mathematics assessment and the quality of the learners' work. On the other, Wellington and Osborne (2001) have identified a connection between developing a language and forming mathematical concepts. Research findings by Henderson and Wellington (1998) and Wellington and Osborne (2001) indicated the importance of language usage in AfL activities in mathematics. The way in which teachers use language in the assessment activities and how learners understand this language can inadvertently affect how learners respond to solutions to mathematical questions.

In this paper, we explore how language affects learner performance in Grade 6 mathematics AfL activities. We seek to respond to the following question:

How do Grade 6 mathematics teachers use the Language of Learning and Teaching in assessment for learning? 


\section{Literature review}

\section{Redefining classroom practices: A story of Assessment for Learning (AfL)}

Assessment is an integral element for effective teaching in mathematics classrooms. It allows the teacher to collect information about the learner, analyse it, and implement corrective measures to remedy the identified learning challenges (Dreyer \& Mawela, 2020). Studies have shown that assessment for learning (AfL) in particular, has a measurable influence on learners' academic achievement and their self-regulatory learning skills (Mehmood et al., 2012; Ozan \& Kincal, 2018; Voinea, 2018). AfL practice is continuous in assisting the teacher to gather information about how learning is taking place and in bringing back information to the learner's awareness. Black and Wiliam (1998, p. 7) articulated that AfL "encompasses all those activities undertaken by the teacher and his/her learners, which provide information to be used as feedback to modify the teaching and learning activities in which they are engaged." The assertion of these scholars is that the teacher must work together with the learners to create authentic information about the learning process to help them both reflect back and decide on the next step in the learning process. This helps by bridging the gap between and among the content presented, the learning goals, and the mathematics skills related to the concept.

\section{Language as central to learner ability in the assessment of mathematics}

The South African education system has adopted a learner-centred approach to classroom instruction (DBE, 2011). Learner-centred pedagogies place the learner at the centre of teaching, learning, and assessment as Moate and Cox (2015) have asserted. Therefore, explicit awareness of the centrality of AfL should be made clear to learners to assist them to bridge the language barrier in assessment in relation to how to explain, reason, and articulate ideas mathematically (Robertson \& Graven, 2018). As indicated above, in the South African education context, most learners do not receive their education in their HL. Therefore, the debate continues about how to ensure that teaching and learning of mathematics can happen in conditions that present barriers to this. Howie et al., (2016) have pointed out that the 2016 results of the Progress in International Reading Literacy Study (PIRLS) paint a devastating picture of South African learners' reading proficiency; 78\% of Grades 4 and 5 learners in South Africa cannot read for meaning in any language .

Mathematics uses internationally recognised numbers, mathematical symbols, and grammar as Leshem and Markivits (2013) have noted. These are linked to the LoLT, regardless of what that language might be. According to Nel (2012), mathematical vocabulary demands are higher than those of ordinary English. For Muller (1993, p. 312), "without an understanding of the vocabulary used routinely in mathematics instruction, textbooks, and word problems, learners are handicapped in their efforts to learn mathematics." Therefore, learning the language of mathematics is an inherent feature of learning mathematics as Lane et al. (2019) have made clear. Teachers' ability to explain mathematical language, that is, the mathematics register (Trinick et al., 2014; Lane et al., 2019) is essential to helping learners construct 
knowledge. Lane et al. (2019, p. 791) have suggested that "it is a discipline-specific and necessary language for the accurate representation and application of mathematical knowledge." Chitera (2011) warned that the teacher's command of the LoLT is a determining factor in how learners perform mathematics. The findings of Yahaya et al. (2009) suggested that teachers whose HL is different from the LoLT struggle to support their learners' development towards understanding the subject content. Thus, teachers resort to codeswitching (CS) in teaching mathematics using a mixture of the HL and English as the LoLT.

In the planning of AfL activities in mathematics, teachers need to consider the language development of learners, the content and concept being taught, and the progression of the concept through the grades (DBE, 2011). For van der Nest et al. (2018, p. 2), to achieve the aim of "education for all" and "inclusivity", there is a constant need to expand the "assessment process to include the other dimensions of mathematics and in the process, enable teachers and learners to address these aspects of mathematics in the learning and teaching process." Therefore, teachers need to take cognisance of learners' language proficiency and ensure that the assessment is accessible to all of them.

\section{Challenge of mathematics assessment in second language speakers}

Assessment and language are interrelated because all assessments are given through the medium of a language. Language mastery inevitably influences how learners respond to the text placed before them.. The mathematics skills that are learned are understood through a language. Therefore, understanding the language becomes a precondition for the thought processes that influence knowledge actualisation in the mastery of mathematics (Botes \& $\mathrm{Mji}, 2010$ ). Lack of understanding because of the language barrier results in inefficient knowledge actualisation as Vygotsky (1989) might have put it. The incomprehension may, in turn, impact "learners' attitude towards mathematics and as a result, their self-efficacy" (Truxaw \& Rojas, 2013, p. 1080). Teachers need to be aware of the challenges which may emerge from learners having to learn mathematics in what is to them a foreign language. For example, learners may find the academic language more challenging than conversational language, which means that working to understand even a basic instruction in a second language can be exhausting. Learners may choose not to participate publicly in activities since asking meaningful questions in a second (or third or fourth) language can be difficult. Learners might also lack the opportunity to learn to reason in their HL, which can hinder sense-making. They may face additional challenges when they are presented with unfamiliar representations and contexts, and, of course, learners are likely to appear (and feel) less intelligent than they are (Truxaw \& Rojas, 2013) when they are unable to express themselves coherently.

\section{Using code-switching (CS) to empower learners in concept development in mathematics assessment}

To date, studies on CS have grown exponentially and are perceived to be a strategy teachers use to disseminate academic information to learners whose HL is different from the LoLT (Maluleke, 2019). Using CS helps the teacher to explain concepts that might be difficult for 
learners to understand, thus minimising confusion among them (Yusob et al., 2018). Therefore, it is of great significance to realise that learners' assessment of mathematics occurs in their use of a language. Teachers and learners use the language to interact and communicate, and therefore, extra support is needed when learners use English as the LoLT to assess mathematics. According to Setati and Adler (2000), CS is an essential resource in "multilingual primary mathematics classroom" in the South African context (p. 265). Maluleke (2019) stated that teachers use CS to empower learners towards meeting academic goals. Yamat et al. (2011) concur and suggested that CS should be used as a scaffolding mechanism through which learners are assisted progressively toward understanding.

According to Setati (2002, p. 9), because of multilingualism in South African classrooms, mathematics teachers must learn to manage the interaction between and among

- Ordinary English and mathematical English;

- Formal and informal mathematical language;

- Procedural and conceptual discourses; and

- Learners' primary language and the LoLT.

While it is clear that mathematics teachers should assist learners in drawing from their HL towards concept development (Setati \& Adler, 2000), discussions regarding the use of CS have been going on for some time. Some researchers maintain that it positively affects classroom instruction (Memory et al., 2018; Shafi et al., 2020; Simasiku, 2016). Others argue that it affects educational attainment and cognitive development negatively (Chikiwa \& Schäfer, 2018; Mokgwathi \& Webb, 2013). In their conclusion, Chikiwa \& Schäfer (2016, p. 254) suggested that "that best practices for code-switching need to be established to promote transparent code-switching that is precise, consistent and beneficial to increasing access to mathematical understanding."

\section{Theoretical Framework}

According to the social constructivist stance on education, learning happens when there is an increased interaction among learners and teachers (Newman et al., 2011). Learner-to-learner and learner-to-teacher close interaction has been found to contribute to an increased learner "motivation and enthusiasm" (Newman et al., 2011, p. 81). Vygotsky (1981) suggested that specific tools such as language, counting systems, and algebraic symbol systems help learners develop communicative and cognitive functions so, what is taught should be mediated through a language that allows the learners and the teacher to communicate ideas (Vygotsky, 2002). The socio-cultural theory acknowledges that "knowledge is socially constructed through interaction and shared by individuals" (Wang et al., 2011, p. 297). Socio-cultural theories explain how cognitive development of a learner ensues through classroom engagement with peers and the teacher in activities using social and cultural contexts (Johnson, 2009). Teachers should be aware that "every function in the child's cultural development appears twice: first between people and then, inside the child" (Vygotsky, 1978, 
p. 57). Through working and communicating with others, the learner develops awareness of self and the skills needed in mathematics.

A widely discussed socio-cultural concept is Vygotsky's (1978) Zone of Proximal Development (ZPD), that he defined as the "distance between the actual developmental level as determined by independent problem solving and the level of potential development as determined through problem solving under adult guidance or in collaboration with capable peers" (p. 86). Vygotsky argued that productive classroom communication and interactions align the teaching of the content within the ZPD, helping the learner to develop required skills. However, we must note that this is facilitated through language. The term ZPD is strongly associated with scaffolding as Mutekwe (2018) has pointed out. According to Wood et al. (1976), scaffolding practices help learners to master a concept taught to a point where they can complete a task on their own. The use of more capable peers to overcome the challenges of the weaker learners in mathematics as in other learning areas, is vital to assist them since learner participation aims at concept development and mastery as Wells (2015) has observed.

\section{Research design and methods}

\section{Research approach and type}

In this qualitative study, part of more extensive doctoral research (see Mahlambi, 2020), we explored the impact of the LoLT on the assessment of mathematics in selected primary schools in Alexandra Township, South Africa. A single case study was considered to be an appropriate method to collect data from the teachers since, in using a case study, a researcher can analyse a situation intensively within a bounded context (Punch, 2009). A case study also allows the researcher to contextualise a phenomenon and understand the participants' social world (Yazan, 2015). For this study, the single case study was comprised of primary school teachers teaching mathematics in Grade 6. The interpretive paradigm helped us interact with the teachers as they interpreted the world around them as Kivunja and Kuyini (2017) have suggested.

\section{Study population and sampling}

Mathematics teachers who participated in this study were selected from nine primary schools in Alexandra Township, South Africa. Purposive sampling was regarded as valid to identify nine teachers who were teaching mathematics in Grade 6. Following Rahi (2017) we used the proximity rule that afforded us greater accessibility to the participants. The criteria used for their selection was that the teacher be teaching mathematics and have a minimum teacher qualification (Diploma in Education). In total, nine Grade 6 mathematics teachers participated in this study. 


\section{Data collection procedures}

Face-to-face semi-structured interviews and non-participant observation were used to collect data. We used semi-structured interviews to elicit teachers' views on the impact of language in mathematics AfL activities in their classrooms. Interviews allow a researcher to initiate the conversation and encourage the participants to articulate their thoughts and opinions (Creswell \& Creswell, 2018). The semi-structured interviews were done in schools at the teachers' convenience so as not to disrupt school activities. We recorded the interviews with the teachers' permission, taking fieldnotes to supplement the recorded information in line with the suggestions made by Efron and Ravid (2013). Nine non-participant observations offered us an opportunity to observe how mathematics teachers and learners interacted using the LoLT in AfL activities. One of us sat at the back of the classroom and documented observations as the teachers and learners engaged with AfL activities. This offered us an opportunity to gather information based on the participants' lived experiences.

\section{Data analysis}

We generated the study's findings from nine face-to-face semi-structured interviews and nine classroom non-participant observations as noted above. Qualitative data analysis (Flick, 2013; Gibbs, 2012) was used to make sense of teachers' views. The process of analysing the data was systematised through thematic organisation. During the analysis of the qualitative data, we were able to make sense of the teachers' views through patterns (Gibbs, 2012) and through developing themes as suggested by Creswell (2013).

\section{Ethics and consent}

Ethical clearance was granted by the University of South Africa (UNISA) with an ethical clearance certificate (Certificate Ref. 2019/08/14/61954705/20/MC). Written permission to conduct research was granted by the Gauteng Province: Department of Basic Education (Ref.2018/327), Johannesburg East District, and Grade 6 mathematics teachers. To protect teachers' identity, pseudonyms were used (MT\#1 to MT\#9) in the reporting process. Data collection was carried out in a way that did not disrupt the teachers' work, and participation was voluntary.

\section{Findings}

The following themes emerged from our analysis of data collected through interviews and non-participant observation.

- Teachers' knowledge of the use of language in assessment for learning activities;

- Mathematics teachers' challenges in assessment for learning activities; and

- Strategies to foster the use of English in the assessment of learners 
Theme 1: Teachers' knowledge of the use of language in assessment for learning activities

The interview data analysis showed that teachers lacked pedagogical knowledge regarding the use of language in AfL activities. How they plan and administer AfL practices towards meeting learners' needs in classrooms lacks cohesion. When asked how they developed and administered assessment for learning activities, the majority of the teachers indicated that the books they use include activities.

We have activities in the books that we use, and the language is not difficult to understand. Yes, our learners struggle to read English, but I am there to assist them whenever the need arises. (MT\#8)

To choose activities, I make use of different textbooks that [are] Curriculum and Assessment Policy Statement compliant. The Department has verified the books therefore the language used in the books is relevant to the standard of our learners. (MT\#2)

I use the Curriculum and Assessment Policy Statement aligned textbooks as well as the Annual Teaching Plan. Should the activities in the books be difficult for learners, I then develop my activities that will be relevant to the concept taught. (MT\#6)

I use the Curriculum and Assessment Policy Statement aligned textbooks . . . The CAPS document tells us what to teach and what schemes to assess, then I get class activities from the textbook. Our learners struggle to read English on their own without the help of the teacher. (MT\#7)

Most teachers who participated in this study admitted that they do not plan assessment activities. It appeared that there was an over-reliance on the use of textbooks for learner AfL activities. Besides, it is evident from the responses above that teachers acknowledge learners' reading challenges and reading through the exercises aloud is part of what they think of as helping the learners to understand the requirements of the activity. Yet, observation revealed that the teachers used time allocated to completing the activity to explain it.

The reflections of two participants identified the need to plan AfL activities beginning with simple terms that learners can read and understand, and then to build on them to more abstract levels.

I use basic language that the learner understands, terms introduced to learners in Grade 4, building it to the level of the current grade. This assists me in catering for learners' language needs. (MT\#2)

I try and develop the mathematics activities that simplify the complex language in mathematics. (MT\#9) 
Both excerpts above indicate that teachers understand the importance of language in AfL activities. Because concepts and mathematical ideas are communicated in English, teachers need to simplify these according to their learners' language proficiency. For example, the concepts "mean" and "mode" have different meanings according to mathematical and ordinary English. Although teachers could not explain these terms in learners' HL, they used mathematical calculations to simplify them.

Theme 2: Mathematics teachers' challenges in assessment for learning activities

All teachers indicated that the number of learners in their mathematics classroom poses a challenge to applying AfL practices. Learners often become disruptive in overcrowded classrooms and this creates a sterile working environment. Teachers stated that the language used in learners' assessment also poses a barrier to learner independence (see Mahlambi, 2020). The non-participant observation revealed that because most learners struggled with the language and could not work independently, the teachers needed to read through the questions, so they did so while explaining the requirements and pointing to the examples on the board. It was clear that teachers understand the challenges created by language in the assessment.

The biggest barrier in assessment is the language used in the assessment activities. Learners find it difficult to understand English and, without my help in explaining questions, learners experience difficulties in completing assessment activities. (MT\#9)

If I take an activity and give to learners without any explanation, very few can attempt to complete the activity. (MT\#1)

After teaching a concept and having given examples on the board, I still have to give clarity on the classroom exercise. Language is a challenge. (MT\#7)

The observations revealed that in many cases, learners could not complete the activity within the time allocated to it since much time was consumed in having the teachers explain the requirements of the activities. The time (an hour) allocated to teaching and assessing learners was insufficient for the teacher to give feedback that could assist in concept development and help learners improve on their practice.

An additional challenge to teachers is that the policy on progression requirements implemented in the Intermediate Phase creates a challenge in Grade 6. One teacher was very concerned about the learner progression policy and said,

Policy on progressing learners between grades failed to observe the amount of work these learners have to cover in a year. When I teach a topic, I fail to incorporate the building up of the concept from Grade 4 to assist the progressed learners. My learners face serious problems; first, mathematics skills and second, the use of language in mathematics. (MT\#7) 
The statement above suggests that the policy on the progression of learners impacts their performance. The teacher felt overburdened in meeting policy needs in terms of dealing with the mathematical concepts covered in Grade 6 while having learners in the classroom who lack the necessary mathematical skills and the language proficiency to engage with these concepts.

\section{Theme 3: Strategies to foster the use of English in the assessment of learners}

Continuous professional development is central to teacher upskilling. Teachers expressed the need for workshops that could help them with English skills as First Additional Language in mathematics. One of the teachers stated,

I am not an English teacher, and maybe the language I use doesn't make sense to the learners. I, therefore, need support from the departmental officials in the district office, especially language specialists. The officials need to come to schools and provide us with skills to simplify the language we use in mathematics. (MT\#3)

Another teacher said,

I am beginning to think that my learners do not achieve because they do not understand English. There is a correlation between understanding the language of teaching and learning and the learners' ability in mathematics. I need guidance from language experts on how to use English to the advantage of learners. (MT\#7)

Other teachers echoed a similar sentiment regarding introductory workshops.

The last time I received developmental in-service training was in 2012 when the Department of Education introduced CAPS. Even then, I was told assessment for learning is informal assessment. The impact of language on assessment was not well articulated enough. (MT\#3)

I am a registered student with one of the universities, and I must say it has helped me to try and bridge the language gap experienced by mathematics teachers. (MT\#4)

In line with the above responses, another teacher cited the need for quality in all AfL activities in mathematics.

I need a developmental workshop that will identify quality rather than quantity as a prerequisite for assessment for learning activities. At the moment it is about the number of activities given to learners. Not much is being said about the quality of activities given to learners. I think that kills the whole idea of teaching and learning mathematics. (MT\#8)

The language used in assessment is vital when it comes to learner engagement and participation. How the mathematics teacher explains and elaborates the concepts has a bearing on how the learners will understand, and therefore, how they will attempt to complete 
the task placed before them. As observed, learners lacked proficiency in the LoLT, which obstructed their engagement with AfL activities. Most teachers elected to read and explain the activities to learners using HL to address learners' lack of English language proficiency. This lack of language ability affected how learners engaged among themselves in groups, and the majority of learners decided not to engage with other group members. In trying to bridge the gap caused by the language barrier, mathematics teachers had to switch between learners' LoLT and their HL. Also, issues have arisen from the translation of mathematical terms. For example, there are no African terms for concepts assessed such as mean, mode, and median. This means that in addition to learners needing to develop English language proficiency, they need to be able to create mathematical discourse. Learner proficiency in mathematics depends on their ability to compute and communicate using mathematics-specific terms (Gürefe, 2018).

Most teachers used CS, a mixture of different African languages spoken by learners and by themselves. Observation revealed that in most cases, the HLs between teachers and learners differed and also between learners. In one classroom observed, the teacher was Sesothospeaking, and the learners were a mixture of Sesotho- and IsiZulu-speakers. Therefore, the teachers' explanations did not reach the whole class, but only the learners who spoke Sesotho. The teacher-learner engagement benefitted only those learners conversant with the language/s used in class since this meant that they could engage and ask follow-up questions. Discussions that ensued in groups took place in learners' HL, and learners' input could be measured in terms of how well they understood the teacher. Most learners worked through the activities without contributing to group discussions, and this could be attributed to their not speaking the same HL as the mathematics teacher.

\section{Discussion}

In this study, we aimed to explore Grade 6 mathematics teachers' use of the LoLT in AfL. As mentioned above, we framed the question as "How do Grade 6 mathematics teachers use the Language of Learning and Teaching in assessment for learning?" As we know, the literature concludes that language plays a central role in learners' academic ability and achievement (Craig \& Morgan, 2015; Cross et al., 2018; Mulwa, 2014; Robertson \& Graven, 2018). According to Riccomini et al. (2015), learner development in the LoLT and mathematics vocabulary is necessary to assist them to access concepts and instructions. As Vygotsky (2002) asserted, teacher-learner interaction is mediated through a language so, for improved learner interaction, mathematics teachers need to understand the language developmental stages of second language users (Cummins, 1979, 2000). To attend to the challenges posed by language, the teachers we observed read through the activity, explained what should be done, and then pointed learners back to the examples on the board. This practice seems to point to their very limited understanding of the notion of the ZPD that includes tasks learners can complete without assistance, those they can manage with assistance, and those that they cannot meet even with help (Sarker, 2019). 
Following the notion confirmed by Gürefe (2018) that learner academic performance in mathematics is also reliant on their ability to communicate using mathematic-specific terms as well as their ability to complete mathematical computations, we report that understanding the language of mathematics is vital to improving learner proficiency. The learners' inadequate comprehension of assessment activity requirements challenges their contribution and prevents their completion of such tasks. This means that the use of CS to understand the teaching and learning process and the provision of the assessment activity has become the norm in many South African classrooms where the LoLT is not fully developed or is limited in learners (Maluleke, 2019).

English is used as the LOLT in most Grade 6 classrooms in South Africa. This means that mathematics teaching, learning, and assessment are done through a language that is considered foreign to many learners who are introduced to English as the LOLT only at the Grade 4 level. However, policy requires that an additive bilingual approach is used in the Foundation Phase, where the learners' HL continues to be developed while a second language such as English is introduced (DBE, 2011). The teaching of mathematics requires learners to read, write, listen, and engage in discussions using a language in which they are proficient, which could either be the HL or the LoLT. To improve the use of language used in the mathematics classroom to enhance the teaching and learning process and AfL in mathematics, teachers should strengthen specific pedagogical skills. It was evident from this study's findings that mathematics teachers should have well-prepared activities that support learning and take into consideration learners' language abilities and level of proficiency. Mathematics teachers need to make sure that the use of language in AfL activities is appropriate and that it supports the learning and development of learners' mathematical skills.

However, if language proficiency hinders learner understanding, CS is a viable strategy that empowers learners to enhance their academic performance in mathematics (Lee et al., 2010; Maluleke, 2019; Setati, 1998; Yamat et al., 2011) and prevents the fostering of a fear of mathematics in them. In this small-scale study, mathematics teachers' use of CS helped learners understand the requirements of the activities. It is through language, whether the HL or the LoLT, that a bond will be developed between teachers and learners that will then inspire the latter and build competence in them along with the confidence to deal with any mathematical situation and this will result in a spirit of curiosity and a love of the subject (DBE, 2011).

\section{Conclusion}

We conclude from this small-scale study that AfL in mathematics is not fulfilling its duty of supporting mathematics teaching and learning. Our findings revealed that learners in the participating schools in Alexandra face a challenge in understanding mathematics taught in English, which is the learners' First Additional Language. We acknowledge that the mathematics teachers who participated in this study need assistance in improving language usage in mathematics teaching. Teacher training towards further development is the only 
possible option for addressing this problem. Mathematics teachers in Grade 6 need in-service training to ensure that they plan their AfL activities in the most appropriate language for their learners. Important mathematical concepts should be well researched in the learners' language and presented clearly so that an understanding of their definition makes an impact on their learning of mathematics. Relying on the activities in the textbooks is not sufficient since these do not take into account the language context of the learner.

\section{Acknowledgement}

We acknowledge the mathematics teachers who participated voluntarily in this study. The high quality editorial work done by Dr C. Dowse and the language revision done by the University's Language Services are highly appreciated. We acknowledge that the opinions, findings, and conclusions expressed in this paper are those of the authors.

\section{References}

Benson, C. (2004). The importance of mother tongue-based schooling for educational quality. (Background paper prepared for the Education for All Global Monitoring Report 2005: The Quality Imperative). UNESCO. https://unesdoc.unesco.org/ark:/48223/pf0000146632

Black, P., \& Wiliam, D. (1998). Assessment and classroom learning. Assessment in education. Principles, Policy \& Practice, 5(1), 7-14. https://doi.org/10.1080/0969595980050102.

Botes, H., \& Mji, A. (2010). Language diversity in the mathematics classroom: Does a learner companion make a difference? South African Journal of Education, 30, 3-8.

Boulet, G. (2007). How does language impact the learning of mathematics? Let me count the ways. Journal of Teaching and Learning, 5(1), 1-12.

Chikiwa, C., \& Schäfer, M. (2016). Teacher code-switching consistency and precision in a multilingual mathematics classroom. African Journal of Research in Mathematics, Science and Technology Education (AJRMSTE), 20(3), 244-255.

Chikiwa, C., \& Schäfer, M. (2018). Promoting critical thinking in multilingual mathematics classes through questioning. EURASIA Journal of Mathematics, Science and Technology Education, 14(8), 1-15.

Chitera, N. (2011). Language of learning and teaching in schools: An issue for research in mathematics teacher education? Journal of Mathematics Teacher Education, 14(3), 231-246. 
Craig, T., \& Morgan, C. (2015). Language and communication in mathematics education. In S. Cho (Ed.), The proceedings of the 12th international congress on mathematical education (pp. 529-533). Springer International Publishing.

Creswell, J. W. (2010). Qualitative inquiry and research design. Choosing among five traditions. SAGE.

Creswell, J. W. (2013). Qualitative inquiry and research design: Choosing among five traditions (3rd ed.). SAGE.

Creswell, J. W., \& Creswell, J. D. (2018). Research design: Qualitative, quantitative \& mixed methods approaches (5th ed.). SAGE.

Cross, A. M., Archibald, L. M. D., \& Joanisse, M. F. (2018). Mathematical abilities in children with developmental language disorder. Health and Rehabilitation Sciences Publications, 14, 1-47. https://ir.lib.uwo.ca/hrspub/14

Cummins, J. (1979). Cognitive/academic language proficiency, linguistic interdependence, the optimum age question and some other matters. Working Papers on Bilingualism, 19. 198-205. https://files.eric.ed.gov/fulltext/ED184334.pdf

Cummins, J. (2000). Language, power and pedagogy: Bilingual children in the crossfire. Multilingual Matters.

Department of Basic Education. (2011). Curriculum and Assessment Policy Statement: Mathematics Foundation Phase. Government Printer.

Department of Basic Education. (2014). Report on the annual national assessments of 2014: Grades $1-4$ \& 9. Government Printer.

Department of Basic Education. (2017). The SACMEQ IV project in South Africa: A study of the conditions of schooling and the quality of education. Government Printer.

Dreyer, J. M., \& Mawela S. A. (2020). The educator as assessor in the Intermediate Phase (1st ed.). Van Schaik.

Efron, E. S., \& Ravid, R. (2013). Action research in education: A practical guide. The Guilford Press.

Flick, U. (2013). The SAGE Handbook of Qualitative Data Analysis. SAGE

Gibbs, G. R. (2012). The nature of qualitative analysis: Analysing qualitative data. SAGE.

Gürefe, N. (2018). Mathematical language skills of mathematics prospective teachers. Universal Journal of Educational Research, 6(4), 661-671. 
Henderson, J., \& Wellington, J. (1998.) Lowering the language barrier in learning and teaching science. The School Science Review, 79(288), 35-46.

Howie, S. J., Combrinck, C., Roux, K., Tshele, M., Mokoena, G. M., \& McLeod, P. N. (2016). PIRLS Literacy 2016: South Africa Grade 4 literacy 2016 highlights report, South Africa. http://doi.org/10.13140/RG.2.21111073282.

Johnson, K. E. (2009). Second language teacher education: A socio-cultural perspective. Journal of Child Psychology and Psychiatry, 17(2), 89-100.

Khatib, M., \& Taie, M. (2016). BICS and CALP: Implications for SLA. Journal of Language Teaching and Research, 7(2), 382-388.

Khurana, P., \& Sharma, S. (2015). Role of language in teaching-learning science: Experiences of pre-service student teachers. Scholarly Research Journal for Humanity Science \& English Language, 4(19), 4396-4404.

Kivunja, C., \& Kuyini, A. B. (2017). Understanding and applying research paradigms in educational contexts. International Journal of Higher Education, 6(5), 26-41.

Lane, C., O'Meara, N., \& Walsh, R. (2019). Pre-service mathematics teachers' use of the mathematics register. Issues in Educational Research, 29, 790-806.

Lee, H., \& Lee, J. (2010). Code-switching in the teaching of English as a second language to secondary school students. Malaysian Journal of ELT Research, 6, 1-45.

Leshem, S., \& Markivits, Z. (2013). Mathematics and English, two languages: Teachers' views. Journal of Education and Learning, 2(1), 211-221.

Mahlambi, S. B. (2020). Assessment for learning: An approach towards enhancing quality in mathematics teaching and learning (Unpublished doctoral dissertation). University of South Africa, Pretoria, RSA.

Maluleke, M. (2019). Using code-switching as an empowerment strategy in teaching mathematics to learners with limited proficiency in English in South African schools. South Africa Journal of Education, 39(3), 1-9.

Mehmood, T., Hussain, T., Khalid, N., \& Assam, R. (2012). Impact of formative assessment on academic achievement of secondary school students. International Journal of Business and Social Science, 3(17), 101-104.

Memory, N. D., Nkengbeza, D., \& Liswaniso, C. M. (2018). The effects of code-switching on English language teaching and learning at two schools in Sibbinda Circuit. International Journal of English Language Teaching, 6(5), 56-68.

Moate, R. M., \& Cox, J. A. (2015). Learner-centred pedagogy: Considerations for application in a didactic course. The Professional Counsellor, 5(3), 379-389. 
Mokgwathi, T., \& Webb, V. (2013). The educational effects of codeswitching in the classroom - benefits and setbacks: A case of selected senior secondary schools in Botswana. Language Matters, 44(3), 108-125 https://doi.org10.1080/10228195.2013.839734.

Moser, A., \& Korstjens, I. (2018). Practical guidance to qualitative research. Part 3: Sampling, data collection and analysis. European Journal of General Practice, 28(1), 9-18.

Mullis, I. V. S., Martin, M. O., Foy, P., \& Hooper, M. (2016). TIMSS 2015 International results in mathematics. http://timssandpirls.bc.edu/timss2015/international-results/

Mulwa, E. C. (2014). The role of the language of mathematics in students' understanding of number concepts in Eldoret municipality, Kenya. International Journal of Humanities and Social Science, 4(3), 264-274.

Mutekwe. E. (2018). Using a Vygotskian socio-cultural approach to pedagogy: Insights from some teachers in South Africa. Journal of Education, 71, 58-72.

Naziev, A. (2018). The role of language in teaching and learning mathematics. Broad Research in Artificial Intelligence and Neuroscience, 9(1), 114-124.

Nel, C. (2012). Cracking the vocabulary code in mathematics in the Foundation Phase. South African Journal of Childhood Education, 2(2), 15-34.

Newman, T., Olle, M., \& Bradley, C. (2011). Social interaction as a contributor to significant learning outcomes in online instruction. International Journal of Instructional Technology and Distance Learning, 8(11), 79-86.

Organisation for Economic Co-operation and Development (OECD). (2019). PISA 2018 Results (Vol. I): What students know and can do. OECD Publishing. https://oecd.org/pisa/publications/pisa-2018-results-volume-i-5f07c754-en.htn

Ozan, C., \& Kincal, R. Y. (2018). The effects of formative assessment on academic achievement, attitudes towards the lesson, and self-regulatory skills. Educational Sciences: Theory and Practice, 18(1), 85-118.

Prochazkova, L. T. (2013). Mathematics for language, language for mathematics. European Journal of Science and Mathematics Education, 1(1), 23-28.

Punch, K. F. (2009). Introduction to research methods in education (1st ed.). SAGE.

Rahi, S. (2017). Research design and methods: A systematic review of research paradigms, sampling issues and instruments development. International Journal of Economics \& Management Sciences, 6(2), 2-5. 
Recber, S., Isiksal, M., \& Koç, Y. (2018). Investigating self-efficacy, anxiety, attitudes and mathematics achievement regarding gender and school type. Anales de Psicologia, 34(1), 41-51.

Riccomini, P. J., Smith, G. W., Hughes, E. M. \& Fries, K. M. (2015). The language of mathematics: The importance of teaching and learning mathematics vocabulary. Vocabulary, Reading \& Writing Quarterly, 31(3): 235-252.

Robertson, S., \& Graven, M. (2018). Language as an inclusive or excluding factor in mathematics teaching and learning. Mathematics Education Research Journal, 3, 77101.

Sarker, M. F. (2019). Zone of proximal development. International Journal of Advancements in Research \& Technology, 8(1), 27-47.

Sepeng, P. (2013). Exploring mathematics classroom practices in South African multilingual settings. Mediterranean Journal of Social Sciences, 4(6), 627- 638. http://doi.org/10.5901/mjss.2013.v4n6p627.

Setati, M. (1998). Code-switching in a senior primary class of second-language mathematics learners. For the Learning of Mathematics, 18(1), 34-40.

Setati, M., \& Adler, J. (2000). Between languages and discourses: Language practices in primary multilingual mathematics classrooms in South Africa. Educational Studies in Mathematics, 43, 243-269. https://doi.org/10.1023/A:1011996002062.

Setati. M. (2002). Researching mathematics education and language in multilingual South Africa. The Mathematics Educator, 12(2), 6-20.

Shafi, S., Kazmi, S. H., \& Asif, R. (2020). Benefits of code-switching in language learning classroom at the University of Education Lahore. International Research Journal of Management, IT \& Social Sciences, 7(1), 227-234.

Sibanda, J. (2017). Language at the Grade three and four interfaces: The theory-policypractice nexus. South African Journal of Education, 37(2), 1-9.

Simasiku, L. (2016). The impact of code-switching on learners' participation during teaching practice. Studies in English Language Teaching, 4(2), 157-169.

Spaull, N. (2013). South Africa's education crisis: The quality of education in South Africa 1994-2011. Centre for Development \& Enterprise.

Trinick, T., Meaney, T., \& Fairhall, U. (2014). Teachers learning the registers of mathematics and mathematics education in another language: An exploratory study. The International Journal on Mathematics Education, 46(6), 953-965. 
Trudell, B. (2016). The impact of language policy and practice on children's learning: Evidence from Eastern and Southern Africa. UNICEF Eastern and Southern Africa Regional Office (ESARO), Basic Education and Gender Equality (BEGE) Section.

Truxaw, M. P., \& Rojas, E. D. (2014). Challenges of learning mathematics in a second language. Journal of Urban Mathematics Education, 7(2), 21-30.

Van der Nest, A., Long, C., \& Engelbrecht, J. (2018). The impact of formative assessment activities on the development of teacher agency in mathematics teachers. South African Journal of Education, 38, 1-10.

Voinea, L. (2018). Formative assessment as assessment for learning development. Journal of Pedagogy, 1, 7-23.

Vygotsky, L. S. (1978). Mind in society: The development of higher psychological processes. Harvard University Press.

Vygotsky, L. S. (1981). The instrumental method in psychology. In J. Wertsch (Ed.), The Concept of Activity in Soviet Psychology (pp. 3-35). Armonk.

Vygotsky, L. S. (1989). Thought and Language. Halliday Lithograph.

Vygotsky, L. S. (2002). Thought and language (13th ed.). MIT Press.

Wang. L, Bruce, C., \& Hughes, H. (2011) Sociocultural theories and their application in information literacy research and education. Australian Academic \& Research Libraries, 42(4), 296-308. https://doi.org/10.1080/00048623.2011.10722242.

Webb, L., \& Webb, P. (2013). Teaching strategies in language-diverse mathematics class: A case study. Education Research for Social Change, 2(2), 31-42.

Wellington, J., \& Osborne, J. (2001). Language and literacy in science education. Open University Press.

Wells, G. (2015). Dialogic inquiry: Towards a socio-cultural practice and theory of education. Social Work Research, 19(1), 33-37.

Wilson, S. (2015). "I was in year 5 and I failed maths": Identifying the range and causes of maths anxiety in first year pre-service teachers. In M. Marshman, V. Geiger \& A. Bennison (Eds.). Mathematics education in the margins: Proceedings of the 38th annual conference of the Mathematics Education Research Group of Australasia (pp. 643-650). MERGA.

Wood, D., Bruner, J., \& Ross, G. (1976). The role of tutoring in problem solving. Journal of Child Psychiatry and Psychology, 17, 89-100. 
Yahaya, M., Mokhtar, A., Rawian, R., Othman, M., \& Jusoff, K. 2009. Teaching of mathematics and science in English: The teachers' voices. English Language Teaching, 2(2): 141-147.

Yamat, H., Maarof, N., Noorizan, T., Maasum, T., Zakaria, E., \& Zainuddin, E. (2011). Teacher's code-switching as scaffolding in teaching content area subjects. World Applied Sciences Journal 15 (Innovation and Pedagogy for Lifelong Learning, 15, $18-22$.

Yazan, B. (2015). Three approaches to case study methods in education: Yin, Merriam, and Stake. The Qualitative Report, 20(2), 134-152.

Yusob, K. F., Nassir, A. A., \& Tarmuji, N. H. (2018). Code-switching in mathematics classroom: Relationship between students' attention and attitude and their learning success. LSP International Journal, 5(1), 59-69. 